This item was submitted to Loughborough's Research Repository by the author.

Items in Figshare are protected by copyright, with all rights reserved, unless otherwise indicated.

\title{
When soft law overshadows other European resources: Portuguese reconciliation policies and usages of Europe
}

PLEASE CITE THE PUBLISHED VERSION

http://www.ejss.eu/table_of_content.aspx?sy=2011\&pn=1

\section{PUBLISHER}

(C) Intersentia

VERSION

AM (Accepted Manuscript)

\section{PUBLISHER STATEMENT}

This work is made available according to the conditions of the Creative Commons Attribution-NonCommercialNoDerivatives 4.0 International (CC BY-NC-ND 4.0) licence. Full details of this licence are available at: https://creativecommons.org/licenses/by-nc-nd/4.0/

\section{LICENCE}

CC BY-NC-ND 4.0

\section{REPOSITORY RECORD}

Zartaloudis, Sotirios. 2019. "When Soft Law Overshadows Other European Resources: Portuguese Reconciliation Policies and Usages of Europe". figshare. https://hdl.handle.net/2134/13234. 
This item was submitted to Loughborough's Institutional Repository (https://dspace.lboro.ac.uk/) by the author and is made available under the following Creative Commons Licence conditions.

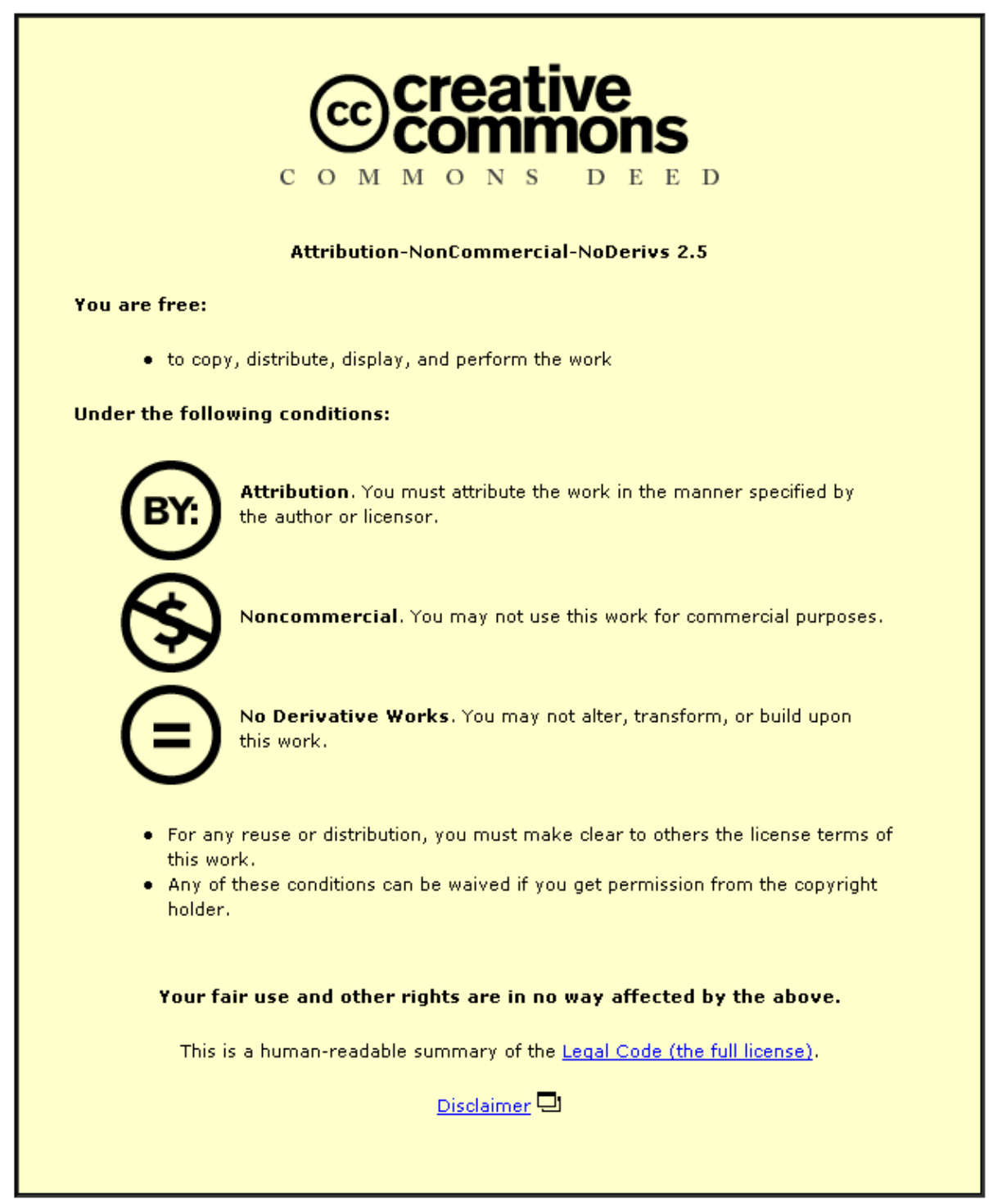

For the full text of this licence, please go to: http://creativecommons.org/licenses/by-nc-nd/2.5/ 


\title{
WHEN SOFT LAW OVERSHADOWS OTHER EUROPEAN RESOURCES: PORTUGUESE RECONCILIATION POLICIES AND USAGES OF EUROPE
}

\author{
SOTIRIOS ZARTALOUDIS*
}

\begin{abstract}
$^{1}$
In the analysis of the usages of Europe in Portuguese reconciliation policies presented in this article, we found a general concordance / temporal sequence between EU and national level developments. In an overall context of limited policy change induced by the EU, the main actors using EU resources were political entrepreneurs: firstly, ministerial elites, and secondly, high-level officials either in government or in the independent bodies for gender equality. These actors used primarily cognitive and financial resources: the European Employment Strategy (cognitive usage), and EU funds (strategic usage), whereas legal resources were not used. Finally, cognitive usage occurred in the beginning of the reform process (the EU was reform initiator) whereas strategic usage took place to support existing goals during the reform process (the EU was reform supporter).
\end{abstract}

Keywords: Portugal; reconciliation; European Union; usages of Europe.

\section{INTRODUCTION}

Along with an analysis of the evolution of Portuguese reconciliation policy, this article examines usages of Europe in this policy field (i.e. policies concerned with the reconciliation between paid work and private life) and is divided into two parts. The first summarises Portugal's relationship to Europe, and its reconciliation policies regime. The second examines the usage of European resources and the role of Europe in the Portuguese reconciliation

\footnotetext{
European Institute, London School of Economics and Political Science, Houghton Street, London WC2A 2AE, London, UK; e-mail: s.zartaloudis@1se.ac.uk

The author is grateful to the task coordinators and members, two anonymous reviewers, and to Kevin Featherstone, Waltraud Schelkle, Christa Van Wijnebergen and Kyriakos Moumoutzis for their constructive comments, which improved this paper. Special thanks go to all Portuguese interviewees for providing their time and help, and the empirical evidence necessary for the completion of this research. All interviewees provided their permission to use the collected empirical evidence in research adn academic outputs. Funding from the Propontis Foundation, Bodossaki Foundation, LSE and RECWOWE is gratefully acknowledged. Any errors are the author's responsibility.
} 
reforms, with a particular focus on who used EU resources in national reforms, and how and why (for the typology used in this article see: Jacquot and Woll 2004). Put differently, this study examines both the degree of substantive policy change and Europe's usages in Portuguese reforms.

The argument presented is three-fold. First, after examining the usages of Europe in Portuguese reconciliation policies, a general concordance between EU and national level developments is found. Second, due to the high degree of centralisation in the Portuguese decision-making system, the national actors who used these resources were political entrepreneurs: ministerial elites and high-level officials either in government or in the country's independent bodies for gender equality. They used primarily soft law and financial resources: the European Employment Strategy (EES) (cognitive usage), and EU funds (strategic usage). No use of legal resources was detected. Finally, cognitive usage occurred in the beginning of the reform process (the EU was reform initiator) whereas strategic usage took place to support existing goals during the reform process (the EU was reform supporter).

This article draws on a variety of sources for its empirical material. In particular, this research drew on qualitative analysis of the existing literature, primary and secondary sources, such as EU and national official documents and European Industrial Relations Observatory (EIRO) reports and evaluations. Moreover, 25 semi-structured interviews with key policymakers (ministerial elites, policymakers, academics, national experts, and delegates in EU institutions) were conducted between March and May 2010. Although a variety of methods was employed in order to achieve triangulation (see Denzin 1970), the main method used in the article is process tracing (see Checkel 2005).

\section{PORTUGAL AND EUROPE: MIND THE GAPS}

This part of the article discusses Portugal's relationship with Europe, and the degree of fit/misfit between its reconciliation policies and EU resources. Regarding the former, three key variables - public opinion, using data from Eurobarometer surveys, the Portuguese government's perceptions of the EU and its social policy initiatives, and patterns of transposition of EU Directives - are examined. Concerning the latter, Portugal's care regime vis-à-vis EU resources is analysed in some detail. 


\subsection{Portuguese attitudes towards Europe: disillusioned public, Europhile elites.}

Since the inclusion of Portugal in Eurobarometer studies in 1985, and until 2001, three main facts stand out from the results (Lobo 2003: 100-103). First, Portugal had one of the highest rates of non-response - a fact that can be interpreted either positively as a sign of 'permissive consensus' (Bacalhau 1993: 182) or negatively as a sign of apathy and hostility towards the national political system and the EU. Second, those who responded were quite positive towards the EU during that period, Portugal was always in the top five countries regarding positive perceptions of the European Union and the impact that EU membership had had on the country's development. The peak (82 per cent) of positive perceptions of Portugal's EU membership was documented in 1991, but decreased considerably to around 67 per cent by 1997, and remained relatively stable until 2001 (Lobo 2003: 102). After 2001, positive Portuguese attitudes towards EU membership decreased further: in 2003, they fell to approximately 57 per cent and remained relatively constant until 2008 (Eurobarometer 2008). The third fact worth noting is that even though the Portuguese public has limited information regarding EU institutions, it trusts them more than national ones. Finally, throughout 19862008, Portuguese respondents, along with their Italian counterparts, remained the most dissatisfied with their life, their national political system, their national welfare state, and their country's economic situation. This pessimistic trend was exacerbated further after the economic crisis of the 2000s and the decade of economic turmoil that followed.

Nonetheless, Portuguese elites view EU membership very positively, much more so than the Portuguese public, creating a significant mismatch between them (cf. Hooghe and Marks 2009). In addition, all Portuguese governments have had very similar positive views regarding the EU (Pizarro 2003: 5) and made similar levels of effort to catch up with the developed EU core members, while respecting the European Social Model (Pizarro 2003: 19). However, there was some nuanced differentiation between the Socialist (PS) governments (1995-2002 and 2005-2010) and Barroso's centre right (PSD-PP) government (2002-2005) with regard to reconciliation policies. Firstly, the latter had a more 'familialistic policy perspective' (Wall and Leitão 2008: 294) as the minister of employment was a member of the conservative People's Party, the ideological foundation of which was based on Christian Democracy. Hence, the government was quite sceptical towards the EU's reconciliation policy. ${ }^{2}$ Secondly, the Portuguese Socialists were strong supporters of the Open

\footnotetext{
Interviews with various Portuguese experts and bureaucrats.
} 
Method of Coordination (OMC) on employment and social protection, inputting into key decisions regarding the EU's social and economic coordination (Cadeiras 2004: 1). In contrast, the Barroso government viewed the OMC as a bureaucratic burden of low - if any value for Portuguese employment policy ${ }^{3}$. Thus, this article will test the following hypothesis: until 2001, when both elites and public opinion favoured Europe and its policies, the usages are expected to be both positive and explicit; subsequently, when public opinion became more critical of the EU and the Barroso government was sceptical of the EU's reconciliation policy, no usage or a denial of usage is expected. In contrast, after 2005 the pro-reconciliation Socialist government is expected to use more European resources in national reforms but in a more subtle fashion than during its previous term in office.

\subsection{Portugal's adaptation to EU social directives: between 'neglect' and 'dead letters'}

In the famous 'worlds of compliance' typology (Falkner et al. 2005), Portugal belongs in the 'world of neglect'. In this type, neither political nor administrative elites adhere to the norm of compliance with EU law (ibid: 325). More recently, Falkner and Treib (2008) renamed this type the 'world of transposition neglect', and added the 'world of dead letters' to their typology. In that type, despite the quick transposition of EU directives, they are not systematically enforced and implemented. Therefore, the impact of EU directives on national policy is doubtful. These two worlds share one key characteristic: compliance is often superficial, since shortcomings in enforcement and application are quite common. Although Falkner and Treib (2008) try to address this conceptual inconsistency by arguing that enforcement and application problems are not the defining characteristics of the world of transposition neglect, this cannot be said for Portugal, since its typical procedural pattern during the transposition stage was neglect, along with significant enforcement and application problems (Falkner et al. 2005: 275). Consequently, Portugal appears to combine the characteristics of both the world of transposition neglect and that of dead letters: namely inactivity / negligence during transposition, and problematic enforcement and application of EU social directives.

\subsection{The Portuguese care regime: A Southern outlier?}

Interview with Mr. Luís Miguel Pais Antunes, Secretary of State for Labour (2002-2005). See also: Zartaloudis 2011. 
The key feature of the provision of social care in Portugal is its 'privatisation' to family members, a characteristic shared by all Mediterranean EU Member States (Daly and Lewis 2000: 289). In addition, concerning both child and elderly care, Leitner (2003: 359) classified Portugal in the 'implicit familiarism' type, that is, a country that 'neither offers defamilisation nor actively supports the caring function of the family through any kind of familialistic policy'. The family remains the principal provider of care as there is no alternative provision of care. Thus, there is an implicit reliance on family for the provision of care (ibid). However, Portuguese parental leave arrangements and childcare facilities (two of Leitner's indicators) have significantly improved since Leitner's study. Since 1999, Portugal has been providing voluntary paternity leave (5 days with 100 per cent income replacement), which became obligatory in 2004. Maternity leave was provided for 18 weeks at a replacement rate of 100 per cent until 2007 and was recently reduced by 1 week (Moss and Corinthus, 2008: 296). Likewise, compared to the mid-1990s, coverage by formalised childcare, both for children aged 0-3 and for children aged 3-6 years, doubled by 2005. This dramatic change was a result of the significant expansion of care facilities since the end of the 1990s. Despite this significant improvement, however, childcare facilities were still insufficient to meet working parents' needs within and beyond school hours (EWCO 2005: 6). The occupation rates of these childcare facilities' were very high (90 per cent) and most of them were full - particularly for the 0-3 group (OECD 2004). Moreover, data showed that coverage by existing facilities remained low. In particular, in 2001, only 15.4 per cent of the 0-3 group were provided with childcare facilities (crèches and nannies), while coverage for pre-school education (3-6) was around 76 per cent in 2002-03 (EWCO 2005). In addition, private childcare services sometimes charge fees that are too high for Portuguese families, thus creating a significant problem for the family budget (Portugal 1999: 241). Nonetheless, it should be stressed that the majority of childcare facilities are owned by the large nongovernmental sector, which is largely funded by the Catholic Church. Indeed, Portugal is an exception in the EU concerning the size of the non-profit 'third' sector - which is neither public nor private - in the provision of childcare services ${ }^{4}$.

Unsurprisingly, the family is still crucial in providing childcare in Portugal - especially for the 0-3 group: almost 90 per cent of children aged 0-3 are cared for by their families

Interview with Paulo J. Santos, Institute of Social Security, IP; Department of Social Development Unit / Social Responses; Head of Sector for Cooperation and Profit Establishments. 
(especially by grandmothers, see Cousins 2000: 117) or in informal care arrangements (usually provided by cheap immigrant labour), and only 12 per cent of this group attend some form of regulated full-day crèche. The mystery of high female employment rates and low childcare provision has puzzled researchers who have not found a definite answer to this paradox. Some authors suggest that Portuguese families either leave their children alone at home or take them to their workplace (EWCO 2005, Torres 2009: 48) whereas others have questioned the reliability and/or comparability of data on Portuguese childcare facilities (Bettio and Plantenga 2004: 101). Surprisingly, qualitative evidence shows that Portuguese families, despite putting more pressure on women to provide childcare, combine all available care options, thus transcending the care/welfare typology, as their choices follow more socioeconomic factors than a national model or culture (Larsen 2004). Nonetheless, childcare provision improves significantly as children grow up, as 60 per cent of children aged 3-6 attend kindergartens, with coverage rising to 90 per cent for those aged 5-6 years and the average coverage for the entire 3-6 group being 76.3 per cent (OECD 2006). Moreover, family provision is highly feminised. Although working hours are gender balanced (around 9 hours per day for men and 8 hours for women), household and family work are not: employed men spend around 1.5 hours per day in unpaid work, whereas employed women spend 4 hours (Perista 2003).

Table 1: Percentage of children (0-3) cared for only by their parents

Source: EU-SILC

\begin{tabular}{|c|c|c|c|}
\hline & $\mathbf{2 0 0 5}$ & $\mathbf{2 0 0 6}$ & $\mathbf{2 0 0 7}$ \\
\hline EU 25 & 51 & 52 & 46 \\
\hline Portugal & 27 & 23 & 37 \\
\hline
\end{tabular}

Table 2: Percentage of children (3-5/6) cared for only by their parents

Source: EU-SILC

\begin{tabular}{|l|c|c|c|}
\hline & $\mathbf{2 0 0 5}$ & $\mathbf{2 0 0 6}$ & $\mathbf{2 0 0 7}$ \\
\hline EU 25 & 12 & 11 & 10 \\
\hline Portugal & 27 & 12 & 11 \\
\hline
\end{tabular}

Table 3: Portuguese participation rates in education and care facilities, as percentage of the child population

\begin{tabular}{|c|c|c|}
\hline Age 0-<3 & Age 3-5/6 & Age 0-5/6 \\
\hline $22 \%$ & $75 \%$ & $65 \%$ \\
\hline
\end{tabular}

Source: Eurostat 
Finally, Portugal has had traditionally low unemployment rates and high employment rates for all groups of the workforce. Female full-time employment has been one of the highest in Europe and almost twice as high as in other Southern European counties. In addition, rates of part-time work for both women and men have been low, a feature that has differentiated Portugal from other European countries in two ways: firstly, in Europe high female employment participation is associated with high female part-time work; secondly, in Southern Europe female employment is traditionally high in the informal economy or inside the house. Nonetheless, a large percentage of the workforce - even by Southern European Standards - and especially women are employed in low-skill jobs (Katrougalos and Lazaridis 2003: 55). Finally, since 2001, the Portuguese economy has entered a long period of recession which has resulted in higher unemployment for everybody, especially for women who, despite maintaining relatively high employment levels, have suffered from a higher unemployment rate than men.

Table 4: Portuguese and EU Employment Rates (1997-2008)

\begin{tabular}{|c|c|c|c|}
\hline & $\mathbf{1 9 9 7}$ & $\mathbf{2 0 0 3}$ & $\mathbf{2 0 0 8}$ \\
\hline Portugal & \multicolumn{3}{|l|}{} \\
\hline Total & $65.7 \%$ & $68.1 \%$ & $68.2 \%$ \\
\hline Males & $75.5 \%$ & $75.0 \%$ & $74.0 \%$ \\
\hline Females & $56.5 \%$ & $61.4 \%$ & $62.5 \%$ \\
\hline EU-27 & \multicolumn{3}{l}{} \\
\hline Total & $60.7 \%$ & $62.6 \%$ & $65.9 \%$ \\
\hline Males & $70.0 \%$ & $70.3 \%$ & $72.8 \%$ \\
\hline Females & $51.4 \%$ & $54.9 \%$ & $59.1 \%$ \\
\hline
\end{tabular}

Source: Eurostat

Table 5: Portuguese Unemployment Rates (1997-2008)

Source: Eurostat

\begin{tabular}{|c|c|c|c|}
\hline & $\mathbf{1 9 9 7}$ & $\mathbf{2 0 0 3}$ & $\mathbf{2 0 0 8}$ \\
\hline Total & $6.7 \%$ & $6.4 \%$ & $7.7 \%$ \\
\hline Males & $8.8 \%$ & $7.3 \%$ & $6.7 \%$ \\
\hline Females & $7.6 \%$ & $7.3 \%$ & $9.0 \%$ \\
\hline
\end{tabular}

Portuguese female employment rates were thus higher than the Lisbon goal of 60 per cent, so there was no misfit between Portugal's performance and the EU's benchmarks. Similarly, there was no misfit concerning Portuguese paternity leave arrangements, since there is no EU directive on paternity leave. Likewise, the EU recommendation for incentives for men to take 
up parental leave included in the Commission's 2006-2010 Roadmap for Equality between men and women (Jacquot et al. 2011) did not create misfit as Portugal had already made paternity leave obligatory in 2004. Hence, no references to or usages of Europe are expected. The misfit between Portuguese and EU standards of maternity and parental leave was also minimal. However, the Barcelona targets of providing childcare for at least 90 per cent of children aged 3-5/6 and at least 33 per cent of 0-3 year olds created a significant misfit. Given that in the last two cases Portuguese standards were lower than the EU ones, it is expected that domestic actors who want to promote reconciliation policies will use EU resources, and that references to Europe will be positive during the national reform processes in order to reduce this misfit between EU and Portuguese policies.

\section{THE SEQUENCE OF REFORMS, AND THE USAGES OF EUROPE: SOFT LAW IN THE DRIVING SEAT?}

This section discusses the main Portuguese reconciliation reforms and the usages of Europe. It is argued that there is a general concordance between EU and national level developments. In addition, the national actors who used these resources were ministerial elites and highlevel officials either in government or in the country's independent bodies for Gender Equality. The EU resources used were primarily cognitive and financial: the European Employment Strategy (cognitive usage), and EU funds (strategic usage). Cognitive usage occurred in the beginning of the reform process (the EU was reform initiator) whereas strategic usage took place to support existing goals during the reform process (the EU was reform supporter). Finally, legal resources were not used, as domestic compliance (where existent) was initiated by the Commission; as a result the EU acted as reform initiator. 
Table 6: Portuguese policy evolution

\begin{tabular}{|l|l|l|}
\hline Policy goals & Policy domains & Policy instruments \\
\hline $\begin{array}{l}\text { 1986-1995 } \\
\text { Reconciliation almost non- } \\
\text { existent }\end{array}$ & $\begin{array}{l}\text { Gender Equality Policy } \\
\text { (anti-discrimination and } \\
\text { equal treatment) }\end{array}$ & $\begin{array}{l}\text { Laws, social pacts: doubtful } \\
\text { implementation (especially in } \\
\text { private sector). }\end{array}$ \\
\hline $\begin{array}{l}\text { Reconciliation to improve } \\
\text { women's situation }\end{array}$ & $\begin{array}{l}\text { Gender Equality Policy } \\
\text { (anti-discrimination and } \\
\text { equal treatment) } \\
\text { Parental Leave } \\
\text { Care facilities }\end{array}$ & $\begin{array}{l}\text { Care facilities' (childcare and } \\
\text { elderly) expansion. }\end{array}$ \\
\hline $\begin{array}{l}\text { 2000-2008 } \\
\text { Reconciliation to promote } \\
\text { employment, activation and } \\
\text { economic growth }\end{array}$ & $\begin{array}{l}\text { Gender Equality Policy } \\
\text { (anti-discrimination and } \\
\text { equal treatment) } \\
\text { Parental leave } \\
\text { Care facilities }\end{array}$ & $\begin{array}{l}\text { Introduction of paternity leave } \\
\text { Care facilities' (childcare and } \\
\text { elderly) expansion. }\end{array}$ \\
\hline
\end{tabular}

\subsection{Legal resources: ignored or unnecessary?}

Although Portugal had to transpose the relevant EU directives, national actors (mainly the Minister of Labour) made few usages of EU legal resources in the numerous legislative reforms of equal pay and leave arrangements. Moreover, Portuguese actors did not actually use the EU's legal resources because the EU Commission initiated the transposition process with the use, or the threat of, the infringement procedures. Subsequently, the Minister of Labour implemented the corresponding legislative reforms to avoid any penalties. Portuguese governments justified reforms by invoking the need for compliance with EU law. The EU obliged Portuguese governments to initiate reforms, and hence, it acted as reform initiator. Finally, the overall importance of the EU's legal resources should not be overstated, as Portuguese law mainly provided higher standards than EU directives.

To begin with, when Portugal joined the EU in 1986, the only EU resources on reconciliation were the directives on equal pay (see Jacquot et al. 2011). However, Portugal did not face a significant 'joining the club effect' as its legal system was already in agreement with the EU standards. Firstly, the 1976 Constitution (Article 59) explicitly prohibited pay discrimination based on gender. Secondly, this principle was fully implemented in 1979 (Decree Law 392) with one of the most progressive equality laws (see Threlfall 1989: 228-229). Both pieces of legislation were the result of small yet activist women's organisations (Barbosa 1989: 478). However, the application and enforcement of equal pay legislation concerns only the public 
sector -where equal pay is the rule- as the private sector gender pay gap remains high as in 2007 it amounted to $22.4 \%$ for gross monthly earnings (Eurofound 2009). Nonetheless, because to the The overall pay gap, as seen in Table 7 ,.

Table 7: Portuguese gender pay gap in public and private sector ${ }^{5}$

\begin{tabular}{|l|c|c|c|}
\hline & $\mathbf{1 9 9 5}$ & $\mathbf{2 0 0 0}$ & $\mathbf{2 0 0 7}$ \\
\hline Private & 25 & 28 & $:$ \\
\hline Public & -12 & -17 & $:$ \\
\hline Total & 5 & 8 & 7 \\
\hline
\end{tabular}

Source: EU-SILC

Table 8: Portuguese gender pay gap ${ }^{6}$ using comparable structure of earnings survey estimates - 2002-2008

\begin{tabular}{|l|c|c|c|}
\hline & $\mathbf{2 0 0 2}$ & $\mathbf{2 0 0 6}$ & $\mathbf{2 0 0 8}$ \\
\hline Portugal & $:$ & 8.4 & 9.2 \\
\hline EU-15 & $:$ & 18.7 & $:$ \\
\hline
\end{tabular}

Source: EU-SILC

Furthermore, Portugal changed maternity leave legislation in the first half of the 1990s in order to comply with the requirements of EU Council Directive 92/85/EEC on the protection of pregnant workers (Math and Meiland 2004). However, maternity leave in Portugal exceeded the 14 weeks required by the directive: it was provided for 18 weeks at a replacement rate of 100 per cent (Wall and Leitão 2008: 291). Likewise, Portuguese law was more favourable than the Parental Leave Directive (96/34/EC) (Math and Meiland 2004, Moss and Corinthus 2008: 104), with the exception of the provisions concerning adoption (Cristovam 1999). Nevertheless, this directive constitutes a prime example of national actors not using the EU's legal resources: Portugal had to be warned by the Commission that it faced infringement proceedings, and it was this threat which led to the establishment of parental leave policies (Lewis and Haas 2005: 349). Subsequently, voluntary parental leave was introduced in 1999, and it only became compulsory in 2004 (Wall and Leitão 2008: 296). As a result, the EU again functioned as a reform initiator.

\subsection{Cognitive and political resources: the main game in town?}

Difference between men's and women's average gross hourly earnings as percentage of men's average gross hourly earnings (for paid employees at work 15+ hours).

Difference between men's and women's average gross hourly earnings as a percentage of men's average gross hourly earnings (for paid employees). 
Since 1998, in response to the EES guidelines and country specific recommendations, Portugal has introduced many policy measures in order to improve the reconciliation of work and family. It is important to note, however, that the EU was not the only external source of such resources for Portuguese policymakers, as reconciliation gained momentum in Portugal with the UN's 1995 'Beijing Platform for Action' on gender equality. This latter was the earliest and most prominent external resource for national actors until its replacement by the EES. As both processes are voluntary for national actors, the incumbent governments' preferences (understood mainly as their ideological orientation towards gender equality) were the main variable that determined the usage of European resources. The introduction of new external resources in the mid-1990s coincided with the election of a pro-gender equality Socialist (centre left) government (1995-2002) which used European resources to promote and enrich its own agenda. The usage of European resources decreased after the formation of the centre-right coalition government of the PSD-PP (2002-2005) which - as mentioned above - had a more 'familialistic policy perspective' and was very sceptical of the OMC and EU reconciliation policy. After 2005, when the Socialists returned to power, national actors used these resources to promote and legitimise their own agenda of expansion of care facilities.

The first major development of the 1990s that aimed to improve the Portuguese reconciliation regime was the 'Global Plan for Equality of Opportunities', approved by the Portuguese government in March 1997. This plan was Portugal's response to a specific recommendation in the Beijing Platform for Action; the concordance between the UN agenda and the government's pre-existing commitment to gender equality promotion led to the first comprehensive programme on gender equality promotion. The importance of the Beijing Platform for Action for the adoption of the 'Global Plan' for gender equality was paramount since, as Portugal (1999) has argued, Portuguese governments have traditionally expressed their commitment to welfare and family policy without implementing concrete policy measures. The plan included 51 measures grouped under seven main objectives - the fourth being the reconciliation of work and private life (CEDAW 1999: 9). This objective was promoted through sensitisation campaigns ${ }^{7}$, the introduction of new ways of organising

Information campaigns, targeted on the public, on the importance of sharing family responsibilities and the balance of the family and the development of children and youngsters. 
working hours, flexibility in working schedules, and the creation of care facilities for dependants (children and the elderly).

Since its launch in 1997, the EES has replaced the UN's Beijing Platform, and Portuguese governments have used the EES to promote the reconciliation of work and private life along the lines of the Global Plan. The structure of the first Portuguese National Action Plan for employment in 1998 mirrored the four-pillar structure of the EES. It included a broad range of measures which supplemented and extended programmes aimed at updating family services, ${ }^{8}$ gradually cultivating the emergence of a new vision regarding care services provision to families with financial difficulties. The concept of a support network, that is, of care services targeting both dependent elderly persons and unemployed women, was a prime example of this new approach to reconciliation policy (Guerreiro 2000: 2). It also contained the elaboration of codes of good practice in companies, vocational training, and an extension of the pre-school network. Furthermore, as a response to the Council's recommendations, the PS government introduced the second National Equality Plan, which covered the period 2003-2006, and included '100 commitments for family policy'. Its implementation was essentially the responsibility of two bodies: the Commission for Equality and Women's Rights and the Commission for Equality in Work and Employment (Pizarro 2003: 7). However, the plan remained mostly on paper, as the level of implementation was extremely low (Rubery et al. 2005: 73). The main reasons for this stalemate were political instability (see Freire and Lobo 2006: 582-583) and the preferences of Portuguese governments during the period 2002-2005, who were not such strong supporters of reconciliation of family and work life as their predecessors. As a result, the aforementioned gender equality bodies responsible for the plan's implementation were practically inoperative (Rubery et al. 2005: 181). This period of instability and antipathy scepticism towards the EES ended in 2005 when the Socialist Party obtained its largest electoral victory, achieving an absolute majority of parliamentary seats for the first time in the party's history (Freire and Lobo 2006). After a long delay, new heads were appointed in 2006 for the two previously mentioned governmental gender equality organisations. Some progress has since been made and this has been subject to an independent external evaluation in 2007 (Rubery et al. 2006: 34).

Two of the most important programmes were the Iniciativas Locais de Emprego (local employment initiatives) and the RIME programme (Regime de Incentivos às Microempresas - micro-enterprise incentive scheme). Of the 4,000 jobs created between 1997 and 1999 under these initiatives, about one third have been in the field of family services or related activities (Guerreiro 2000: 2). 
In addition, the Barcelona targets (set at the 2002 Barcelona European Council) became of paramount significance for the reform of childcare provision. Accordingly, the government introduced its first quantitative targets regarding childcare facilities in the 2001 National Action Plan (NAP), which had to be reached by 2006: access to pre-school education was to be provided to all 5 year olds and to 75 per cent of 3-4 year olds, 1,800 classrooms had to be built and at least 100,000 children aged up to 3 were to attend day nurseries. Moreover, Portugal extended the opening-hours and days of pre-school institutions in order to ensure a functioning scheme and a flexible timetable adequate for family needs (Resolution no. 19 130/2002), and updated its Pre-School Education Expansion and Development Programme (Decree-Law no. 342/2003, of 24th of April). The Portuguese government also regulated the access regime and working rules of the financial support system for the pre-school education establishments of Lisbon's Social Solidarity Private Institutions. In addition, the improvement of crèches was promoted by measures aiming to make their opening-hours more suitable through the implementation of the positive differentiation principle by the Social Solidarity Private Institutions (Cooperation Protocol of 2004), under which, the more children a family would have, the highest the priority in receiving care would be. Finally, the provision of support for unemployed workers' childcare expenses represented a complete departure from traditional public support for childcare, which tended to direct support to institutions rather than families.

The 2005 election and the change of government marked a significant shift in Portugal's efforts to promote the reconciliation of work and family life, and in the extent to which European resources were used. Portuguese policymakers referred to the Council's countryspecific recommendations on Portugal's care facilities ${ }^{9}$ in the 2006 National Reform Plan (NRP), which introduced three new programmes aiming to promote the reconciliation of work and private life by alleviating the burden on women of helping dependants (NRP 2006). The 'Enlargement Programme for the Social Amenities ${ }^{10}$ Network' stipulated effective planning for territorial needs and encouraged investment through partnerships 'between the

Taking measures to combat the factors leading to differences in salaries between men and women in the private sector and increasing the availability of structures to care for children and other dependants, and their accessibility in terms of price.

10

Social amenities are all kind of facilities and/or organisations (care/sports/health/charity/educational/community centres, etc.) that may contribute to the reconciliation of work and private life by providing various activities to dependants, and therefore, alleviating women from their care duties. 
social sector, local power, and the business/private sector' (NRP 2006). The aim of this programme was to improve living conditions for the elderly and the disabled by furthering their autonomy and integration levels. The 'Support Programme for Investment in Social Amenities' (Order in Council no. 869/2006, 29 August) encouraged investment in social amenities that supported private initiatives in order to increase the capacity of care facilities to accommodate dependants. Finally, the 'Network of Integrated Continued Care' aimed to boost the creation of units providing continued healthcare and social support teams for the elderly, operating at the community level.

Moreover, the PS government expanded the Network of Community Proximity Services that was made up of a group of services and social amenities which provided social support and targeted individuals' and families' specific needs. It also extended primary schools' opening hours - children were required to be in school from 09:30 to 17:30 - aiming to assist women in balancing their work and care requirements (Rubery et al. 2006: 137). In addition, the 2006 NRP introduced new targets regarding the provision of care to dependants that had to be achieved by 2009: a 50 per cent increase in the number of crèches to 31,161 units (meeting the Barcelona pledge for childcare facilities for at least 33 per cent of children aged 0-3); employing 19,000 new staff in care facilities for the elderly; and making 6,000 more places available in facilities in the continued integrated care network (a goal to be reached by 2008), and 1,850 additional vacancies in facilities for the disabled by 2009. The government used the Barcelona targets to promote its agenda and mobilise the country's bureaucracy, 'as meeting the EU target was important for the country's reputation' ${ }^{11}$. Overall, in the area of care provision, successive Portuguese governments used (EES) resources to strengthen the provision of care services in order to promote the reconciliation of work and family for women and men. However, the PS governments made more references to Europe and greater use of cognitive resources - especially the EES - and introduced significantly more measures than the PSD-PP government.

\subsection{Financial resources: paying for reconciliation?}

Portugal has received significant economic support from EU Structural Funds. Part of this funding aimed to promote the reconciliation of work and private life. EU financial resources

Interviews with bureaucrats responsible for care facilities, experts on gender equality, and experts on family policy. 
were used in two ways: on the one hand, to support the implementation of certain measures inspired by cognitive resources, thus creating a synergy between these two kinds of resources; on the other hand, as stand-alone EU-financed programmes. With regard to the first category, Portugal used financial resources from the European Fund for Regional Development (EFRD) for the implementation of the UN's Beijing Platform for Action recommendation regarding new care facilities for dependants. Notably, the preamble of the Council of Ministers' resolution approving the plan included no references whatsoever to external resources. Consequently, the usage of European resources in this reform was strategic with the aim of financing a clearly defined policy measure.

In contrast, in the post-EES period there were specific references to Europe's financial resources in the NAPs/NRFs. According to the authors of the 2001 NAP, there was a synergy between European political and financial resources, since the 2001 childcare targets emanate from:

'the guidelines for the EU employment policy for 2001, from the Commission's remarks and from the recommendations to Portugal as per the Joint Report regarding the carrying out of the NAP in 2000 and from the structure and measures included in the new Community Support Framework (CSF) (20002006) which, because it identifies a large part of the financial support of the NAP, exerts a strong influence on the range of instruments available for its carrying out' (NAP 2001: 8).

In this respect, the majority of measures promoting reconciliation under the auspices of the $3^{\text {rd }}$ CSF were included in the $5^{\text {th }}$ axis of the Operational Programme for Employment, Training and Social Development (OPETSD), funded by the EU Structural Funds. One such measure was implemented in 2002, when financial incentives were provided to employers who intended to promote innovation in the organisation of working conditions in order to facilitate the reconciliation between professional and family life for women and men. In addition, during the PSD-PP government term in office, gender equality organisations implemented twenty-six programmes promoting gender equality and reconciliation during the financial year 2003 (CEDAW 2006: 14). Furthermore, during the period 2003-2006, a network of NGOs offering technical and financial support was set up under the OPETSD, implementing 68 projects for the reconciliation of work and family for both sexes. The 
majority of these programmes aimed at changing social stereotypes, via awareness campaigns, in both the public and the private sectors (CEDAW 2008: 15).

The second category of financial resources (stand-alone programmes) included numerous EU-funded measures aimed at promoting the reconciliation of family and work. For instance, Portugal's participation in the EU's Fourth Medium-Term Community Action Programme on Equal Opportunities for Men and Women (1996-2000) included many projects that promoted reconciliation measures and reforms (CEDAW 2001). For example, the project 'For an Active Society', which was funded by the European Commission and promoted by the NGO 'Gräal' along with Portuguese and European NGOs, sought innovative ways to reconcile work and family for both sexes. These solutions were published and discussed in numerous public hearings (CEDAW 1999: 11). Finally, the Community initiative EQUAL (2000-2006) financed numerous programmes that promoted reconciliation for both sexes (CEDAW 2008: $39)^{12}$. These measures were mainly intended to raise awareness regarding gender equality and reconciliation (EIRO 2006: 48). Hence, after 1997, a mix of cognitive and strategic usages is observed. Finally, in those cases where financial resources were used, the EU operated as reform catalyst/supporter.

Table 8 summarises the Portuguese usages of Europe. Although all resources were relevant for domestic reforms, the most important were cognitive and financial ones, whereas legal resources were the least important. Although all governments used EU resources, the PS governments did so much more frequently than the PSD-PP one. Positive strategic usage was the most frequent type of usage, whereas cognitive usage was the most important in terms of agenda setting. Finally, the EU acted mostly as a reform innovator/initiator and reform catalyst/supporter.

Table 9: Portuguese Usages of Europe

\begin{tabular}{|l|l|l|l|}
\hline EU resources & $\begin{array}{l}\text { Actors who used } \\
\text { EU resources }\end{array}$ & Type of Usage & EU role \\
\hline
\end{tabular}
equal opportunities. Source: http://ec.europa.eu/employment_social/equal/mainstreaming/maportugal_en.cfm. 


\begin{tabular}{|l|l|l|l|}
\hline Legal Resources & $\begin{array}{l}\text { Governments } \\
\text { (centre-left) }\end{array}$ & $\begin{array}{l}\text { No direct usage } \\
\text { (need to comply) }\end{array}$ & Reform enforcement agent \\
\hline $\begin{array}{l}\text { Budgetary/Financial } \\
\text { Resources }\end{array}$ & Governments (all) & Positive Strategic & Reform catalyst/supporter \\
\hline $\begin{array}{l}\text { Cognitive/Political } \\
\text { Resources }\end{array}$ & $\begin{array}{l}\text { Governments and } \\
\text { gender equality } \\
\text { organisations }\end{array}$ & $\begin{array}{l}\text { Cognitive and } \\
\text { Positive Strategic }\end{array}$ & Reform innovator/initiator \\
\hline
\end{tabular}

\section{CONCLUSIONS}

National actors in Portugal (ministerial elites and high-level officials either in the executive or in the country's independent bodies for gender equality) used a variety of European resources in their reforms to promote the reconciliation of work and private life, with cognitive and financial resources being the most important ones. Hence, Europe played a significant role in the promotion of the reconciliation of work and private life and in incrementally changing overall Portuguese reconciliation policy. Over the years, as different EU resources became available to domestic actors in Portugal, the usages of Europe evolved: at first, there was no usage (of legal resources); subsequently, usage was significant but remained confined to the ESF/CSF funds (financial resources); however, after 1997, with the EES and the Lisbon Summit, the beginning of the new Structural Funds' Programming Period, and the introduction of the Barcelona childcare targets (cognitive resources), usages of Europe became more frequent and included a combination of cognitive and financial resources.

Since there was no misfit between EU and Portuguese law when Portugal was preparing for EU membership, there was no conditionality or 'joining the club' effect and, consequently, national actors did not use EU resources (the directives on equal pay). Second, although the intensity of usage and references increased in the 1990s, after the early 2000s the usages of and references to Europe decreased (Cadeiras 2004, Pizarro 2003) in line with the decreasing support of the elite and public opinion (see section 2.1 above). In addition, centre-left governments used more European resources and made more references to Europe than the centre-right ones; the fact that the latter were not in favour of the EU's reconciliation policy leads us to confirm the hypothesis regarding the significance of the role of elites' views for 
the extent of the usages of Europe. Finally, when the misfit between EU directives and Portuguese law was small there was no genuine usage of European resources. Likewise, in the case of female employment, there was no usage due to the close fit between national female employment rates and the EES's benchmarks. In contrast, the significant misfit in the case of childcare coverage led to the combined and extensive usage of European (political and financial) resources.

\section{REFERENCES}

Bacalhau, M. (1993) 'The Image, Identity and Benefits of the EC', in Silva Lopes, J. (ed.) Portugal and EC Membership Evaluated, London, Pinter.

Barbosa, M. (1981) 'Women in Portugal', Women's Studies International Quarterly, 4(4), 477-480.

BERR, (2008) 'Employment Relations Research Series No. 100' International Review of Leave Policies and Related Research, July, Department for Business Enterprise and Regulatory Reform (BERR); available at http://www.berr.gov.uk/files/file47247.pdf.

Bettio, F. and Plantenga, J. (2004) 'Comparing Care Regimes in Europe', Feminist Economics, 10(1), 85-113.

Cadeiras, P. (2004) 'National Report for Portugal, 4th Round', in: Govecor (ed.) SelfCoordination at the National Level: Towards a collective "gouvernement économique"? Final Report, April, Cologne.

Committee on the Elimination of Discrimination against Women (CEDAW) (1999-2008) 'Fourth-Seventh periodic report of Portugal'.

Checkel, J. T. (2005) 'It's the Process Stupid! Process Tracing in the Study of European and International Politics', Working Paper No. 26, ARENA Working Papers. Oslo. 
Cousins, C. (2000) 'Women and Employment in Southern Europe: The Implications of Recent Policy and Labour Market Directions', South European Society and Politics, 5(1), 97 122.

Cristovam, M. L. (1999) New measures on parental and family leave - Portugal, EIRO online, accessed at http://www.eurofound.europa.eu/eiro/1999/05/feature/pt9905147f.htm.

Daly, M. and Lewis, J. (2000) 'The Concept of Social Care and the Analysis of Contemporary Welfare States', British Journal of Sociology, 51(2, 281-298.

Denzin, N. K. (1970) The Research Act in Sociology, Chicago: Aldine.

Eurobarometer (2008), Standard Eurobarometer Survey - 70, accessed at: http://ec.europa.eu/public_opinion/archives/eb/eb70/eb70_en.htm

European Industrial Relations Observatory (EIRO) (2006) Reconciliation of work and family life and collective bargaining in the European Union - An analysis of EIRO articles, accessed at http://www.eurofound.europa.eu/eiro/other_reports/work_family_life.pdf

Eurofound (2009) Portugal: Industrial relations profile -2009 , accessed at http://www.eurofound.europa.eu/eiro/country/portugal.htm

European Working Conditions Observatory (EWCO) (2005) Combining family and full-time work: Portugal, accessed at http://www.eurofound.europa.eu/ewco/reports/TN0510TR02/PT0510TR02.pdf

Falkner, G. and Trieb, O. (2008) 'Three worlds of compliance or four? The EU-15 compared to new member states', Journal of Common Market Studies, 46(2), 293-303.

Falkner, G., Trieb, O., Hartlapp, M. and Leiber, S. (2005) Complying with Europe: EU Harmonisation and Soft Law in the Member States, Cambridge, Cambridge University Press. 
Ferreira, A. C. (2003) Conference examines obstacles to equal pay, European Industrial $\begin{array}{llll}\text { Relations } & \text { Observatory accessed }\end{array}$ http://www.eurofound.europa.eu/eiro/2003/04/feature/pt0304102f.htm

Freire, A, and Lobo, M. C. (2006) 'The Portuguese 2005 legislative election: Return to the left', West European Politics, 29(3), 581-588.

Gonzalez, M.P. (2001) Assessment of the National Action Plan for Employment 2002 from a Gender Perspective - Portugal, European Expert Group on Gender and Employment Report to the Equal Opportunities Unit, DG Employment, Brussels.

Guerreiro, M. (2002) Employment, Family and Community activities: A new balance for women and men - Summary of the Portuguese national report, accessed at http://www.eurofound.europa.eu/pubdocs/2000/112/en/1/ef00112en.pdf

Hooghe, L. and Marks, G. (2009) 'A Postfunctionalist Theory of European Integration: From Permissive Consensus to Constraining Dissensus', British Journal of Political Science. 39(1), $1-23$.

Jacquot, S. and Woll, C. (2004) Introduction to Les usages de l'Europe, Acteurs et transformations européennes, Paris, L'Harmattan.

Katrougalos, G. and Lazaridis, G. (2003) Southern European Welfare States: Problems, Challenges and Prospects, Basingstoke, Palgrave Macmillan.

Jacquot, S. Ledoux, C. and Palier, B. (2011) 'Reconciling Paid Work and Private Life" at the EU Level: Instrumentally Diversifying, but Cognitively Narrowing Resources', European Journal of Social Security, 13(1).

Larsen, T. P. (2004) 'Work and Care Strategies of European Families: Similarities or National Differences?', Social Policy and Administration, 38(6), 654-677.

Leitner, S. (2003) 'Varieties of familialism', European Societies, 5(4), 353-375. 
Lewis, S. and Haas, L. (2005) 'Work-Life Integration and Social Policy: A Social Justice Theory and Gender Equity Approach to Work and Family', in Kossek, E. and Lambert, S. J. (eds.) Work and life integration: organizational, cultural, and individual perspectives, Mahwah, NJ, Lawrence Erlbaum Associates.

Lobo, M. C. (2003) 'Portuguese Attitudes towards EU Membership: Social and Political Perspectives', South European Society and Politics, 8(1), 97-118.

Math, A. and Meiland, C. (2004) Family-related leave and industrial relations, EIRO, available at http://www.eurofound.europa.eu/eiro/2004/03/study/TN0403101S.htm

Moss, P. and Corinthus, M. (eds.) (2008) International Review of Leave Policies and Related Research 2008, Employment Relations Research, Series No. 100, available at http://www.berr.gov.uk/publications

NAP (1998-2005) National Action Plan for Employment - Portugal, (various years).

NRP (2005-2007) National Reform Programs - Portugal, (various years).

OECD (2006) Starting Strong II: Early childhood education and care, Paris.

OECD (2004) Babies and Bosses (Vol. 3): New Zealand, Portugal and Switzerland, Paris.

Perista, H. (2003) 'Time, paid and unpaid work in Portugal - A gender issue', Working Paper No.4, Centre for the Study of Law and Policy in Europe, University of Leeds.

Pizarro, N. (2003) 'GOVECOR National Report for Portugal - Third Round', available at http://www.govecor.org/data/20030616175745_Portugese_Report3_final.pdf

Portugal, S. (1999) 'Family and Social Policy in Portugal', International Journal of Law, Policy and the Family, 13(3), 245-246.

Rubery, J., Grimshaw, D., Figueiredo, H., Smith, M., Donelly, R. (2005) 'The National Reform Programme 2004 and the gender aspects of the European Employment Strategy. The 
co-ordinators' synthesis report prepared for the Equality Unit' Final Report, Brussels, European Commission.

Rubery, J., Grimshaw, D., Smith, M., Donelly, R. (2006) 'The National Reform Programme 2005 and the gender aspects of the European Employment Strategy. The co-ordinators' synthesis report prepared for the Equality Unit', Final Report, Brussels, European Commission.

Threlfall, M. (1989) 'Social Policy towards women in Spain, Greece and Portugal' in Gallagher, T. and Williams, A.M. (eds.) Southern European Socialism: Parties, elections and the challenge of government, Manchester and New York, Manchester University Press.

Torres, A. (2009) 'Women, Gender and Work: The Portuguese Case in the Context of the European Union', International Journal of Sociology, 38(4), 36-56.

Wall, K. and Leitão, M. (2008) 'Portugal' in Moss, P. and Corinthus, M. (eds.) International Review of Leave Policies and Related Research 2008, Department for Business Enterprise and Regulatory Reform (BERR) Employment Relations Research, Series No. 100, available at http://www.berr.gov.uk/publications

Wall, K., Aboim, S. Cunha, V. and Vasconcelos, P. (2001) 'Families and informal support networks in Portugal: the reproduction of inequality', Journal of European Social Policy, 11(3), 213-233.

Zartaloudis, S. (2011) 'A Compass or a Spear? The partisan usage of Europe in Portuguese Employment-Friendly Reforms' in P. Graziano, S. Jacquot and B. Palier (eds.) The EU and the Domestic Politics of Welfare State Reforms: Europa, Europae, Basingstoke and New York: Palgrave Macmillan. 